\title{
Spotted fever group Rickettsia infecting ticks (Acari: Ixodidae) in the state of Santa Catarina, Brazil
}

\author{
Alessandra Pereira Medeiros' ${ }^{1}$, Antonio Pereira de Souza', Anderson Barbosa de Moura', \\ Marcia Sangaletti Lavina', Valdomiro Bellato', Amélia Aparecida Sartor', \\ Fernanda Aparecida Nieri-Bastos², Leonardo José Richtzenhain², Marcelo Bahia Labruna²/+
}

\footnotetext{
'Departamento de Medicina Veterinária, Centro de Ciências Agroveterinárias, Universidade do Estado de Santa Catarina, Lages, SC, Brasil ²Departamento de Medicina Veterinária Preventiva e Saúde Animal, Faculdade de Medicina Veterinária e Zootecnia, Universidade de São Paulo, Av. Prof. Orlando Marques de Paiva 87, 05508-270 São Paulo, SP, Brasil
}

During 2006-2008, a total of 260 adult ticks were collected from domestic and wild animals in different regions of the state of Santa Catarina (SC), Brazil, including areas where human cases of Brazilian spotted fever have been reported. Collected ticks belonging to nine species (Amblyomma aureolatum, Amblyomma cajennense, Amblyomma dubitatum, Amblyomma longirostre, Amblyomma ovale, Amblyomma tigrinum, Dermacentor nitens, Rhipicephalus microplus and Rhipicephalus sanguineus) were tested by polymerase chain reaction (PCR) for rickettsial infection. Overall, eight (3.1\%) ticks were found to be infected with Rickettsia species. After sequencing the PCR products, we determined that the sequences generated from three A. aureolatum, one A. ovale and one $\mathrm{R}$. sanguineus from the municipality of Blumenau, one A. ovale from the municipality of Águas Mornas and one A. ovale from the municipality of Urussanga were identical to the corresponding partial rickettsial ompA gene sequence of Rickettsia parkeri strain Atlantic rainforest. The sequence generated from one A. longirostre from Blumenau was $100 \%$ identical to the corresponding partial rickettsial ompA gene sequence of Rickettsia amblyommii strain AL. Because R. parkeri strain Atlantic rainforest was recently shown to have caused two cases of human spotted fever in other states of Brazil, the role of this rickettsial agent as a possible etiological agent of spotted fever in SC is discussed.

Key words: Rickettsia - spotted fever - ticks - Amblyomma - Rhipicephalus - Dermacentor

Until recently, the only spotted fever group (SFG) rickettsiosis known to occur in Brazil was Brazilian spotted fever, caused by Rickettsia rickettsii, the most pathogenic SFG species in the world. This pathogen is endemic in the southeastern states [Espírito Santo, Minas Gerais, Rio de Janeiro, São Paulo (SP)] of the country, where it is transmitted to humans chiefly by the tick Amblyomma cajennense but is also transmitted by Amblyomma aureolatum in a few areas of SP (Labruna 2009). From 1990-2009, 627 confirmed cases of Brazilian spotted fever were reported in these southeastern states; the fatality rates varied from $20-33 \%$ among the four states (data available from the Brazilian Ministry of Health site: saude.gov.br). Because most of these cases were diagnosed solely using serological assays employing $R$. rickettsii antigens and because serological crossreactions between all members of the SFG are known to occur (Philip et al. 1978, Parola et al. 2005), technically these cases could have been caused by any SFG species. Therefore, these cases cannot be considered confirmed cases of $R$. rickettsii infection. However, the severe clini-

Financial support: CNPq, FAPESP

+Corresponding author: labruna@usp.br

Received 7 February 2011

Accepted 12 September 2011 cal signs, high fatality rate and epidemiological data suggest that most of these cases were caused by $R$. rickettsii (Lemos et al. 2001, Angerami et al. 2006a, b). In fact, a few of these infections were investigated more thoroughly using molecular methods and were confirmed to be caused by $R$. rickettsii (Nascimento et al. 2005, Rozental et al. 2006, Lamas et al. 2008, Nascimento et al. 2009).

In 2003, cases of Brazilian spotted fever were reported for the first time in the state of Santa Catarina (SC), southern Brazil. Since then, a total of 139 cases have been confirmed in that state alone (from 2003-2009); none of these cases was fatal (data available from the Brazilian Ministry of Health site: saude.gov.br). A recent study compared the clinical pictures of Brazilian spotted fever in SP (southeastern Brazil) and SC (Angerami et al. 2009). These authors called attention to the more severe disease in SP (usually associated with severe haemorrhagic manifestations) and to the frequent occurrence of lymphadenopathy in patients with this disease in SC. Lymphadenopathy was only rarely observed among the cases in SP, as expected for disease caused by $R$. rickettsii (Walker et al. 2008). The SFG disease in SC has been officially treated as Brazilian spotted fever because the laboratory diagnosis has relied upon the seroconversion to $R$. rickettsii antigens. However, because of the absence of lethal cases and the clinical differences with the disease in southeastern Brazil, it has been suggested that a different, currently unidentified SFG Rickettsia species has caused the disease in SC (Angerami et al. 2009, Labruna 2009). 
In the present study we used molecular methods to investigate the presence of Rickettsia species in ticks in different regions of SC, including regions were Brazilian spotted fever cases were recently reported.

\section{MATERIALS AND METHODS}

During 2006-2008, a total of 260 adult ticks were collected from domestic and wild animals in five out of the six official administrative regions of SC (Norte, Região Serrana, Vale do Itajaí, Grande Florianópolis, Sul) as part of an ongoing study on the tick fauna of SC. Due to logistical reasons, we did not sample the region Oeste Catarinense, where no human cases of spotted fever have been reported (Silva 2009). Ticks were identified to the species level according to Barros-Battesti et al. (2006). After being collected from the animals, ticks were preserved in plastic vials containing absolute ethanol until they were processed.

In the laboratory, the ticks were left for at least $1 \mathrm{~h}$ on a sterile paper towel to allow the ethanol to evaporate. Thereafter, the ticks were individually submitted to DNA extraction using the guanidine isothiocyanatephenol technique, as previously described (Sangioni et al. 2005). For every 10 individual ticks, a blank tube was included in the DNA extraction. Samples were tested individually by polymerase chain reaction (PCR) using primers CS-78 and CS-323 targeting a 401-bp fragment of the rickettsial gene glt $A$, as previously described (Labruna et al. 2004). In each set of reactions, negative control tubes containing water and a positive control tube containing DNA of the strain NOD of Rickettsia parkeri were included (Ogrzewalska et al. 2009). Samples that yielded visible amplicons of the expected size by the gltA-PCR were further tested by a second PCR assay using primers $\operatorname{Rr} 190.70 \mathrm{p}$ and $\mathrm{Rr} 190.602 \mathrm{n}$ targeting a 532-bp fragment of the rickettsial gene ompA, as previously described (Regnery et al. 1991). All ompA-PCR amplicons of the expected size were submitted to direct DNA sequencing using an automated ABI Prism $310 \mathrm{Ge}-$ netic Analyzer (Applied Biosystems, Foster City, CA). The BLAST program (National Center for Biotechnology Information, Bethesda, MD) was used to determine the similarities of the partial rickettsial sequences generated in the current study.

\section{RESULTS}

The numbers of ticks per species and per locality collected in the present study are shown in Table. The 260 adult ticks belonged to nine species: 125 A. aureolatum, 82 Amblyomma ovale, 10 Amblyomma tigrinum, 30 Rhipicephalus sanguineus and one Rhipicephalus microplus were collected from domestic dogs, two A. cajennense and five Dermacentor nitens were collected from horses, four Amblyomma dubitatum were collected from capybaras (Hydrochaeris hydrochoerus) and one Amblyomma longirostre was collected from the grounds of a house.

Eight ticks $(3.1 \%)$ were found to be infected with Rickettsia (Table). These eight ticks yielded amplicons of the expected size for both the gltA and ompA PCRs. The products of the omp $A$ PCR were sequenced. The sequences generated from the three $A$. aureolatum, one $A$. ovale and one $R$. sanguineus from Blumenau; the one A. ovale from Águas Mornas and the one A. ovale from Urussanga were all the same and were $100 \%$ identical $(450 / 450)$ to the corresponding ompA sequence of the Atlantic rainforest strain of $R$. parkeri (GQ855237). Each $R$. parkeri-infected tick was collected from different individual dogs. The sequence generated from one A. longirostre from Blumenau was $100 \%$ identical (450/450) to the corresponding ompA sequence of the AL strain of Rickettsia amblyommii (EU274656). We excluded any cross-contamination of our tick samples with DNA from our positive control sample (strain NOD) because the NOD strain of $R$. parkeri differs from the Atlantic rainforest strain by 10 nucleotides in the segment of ompA that was amplified by the primers.

\section{DISCUSSION}

The presence of the Atlantic rainforest strain of $R$. parkeri is reported in SC for the first time. This strain is considered to be pathogenic for humans and it was recently found to be the causative agent of two cases of spotted fever in humans in Brazil, one in SP (Spolidorio et al. 2010) and another in the state of Bahia (BA) (Silva et al. 2011). In addition, in SP, Sabatini et al. (2010) reported that the Atlantic rainforest strain was present in $13.6 \%$ and $1.9 \%$ of $A$. ovale and $R$. sanguineus ticks, respectively, collected from dogs, and in $8.8 \%$ of $A$. ovale ticks collected from vegetation. Because $A$. ovale is an important human-biting tick (Guglielmone et al. 2006), it was suggested to be a vector for the transmission of the Atlantic rainforest strain to humans (Sabatini et al. 2010).

The two cases of human spotted fever caused by $R$. parkeri strain Atlantic rainforest in SP (Spolidorio et al. 2010) and BA (Silva et al. 2011) were clinically similar to the dozens of spotted fever cases that have been reported in SC (Angerami et al. 2009). These cases were characterised by milder haemorrhagic manifestations and no lethality. The BA case also presented with lymphadenopathy, as was also seen in most cases in SC. Therefore, our results highlight the possibility that the spotted fevers in SC have been caused by $R$. parkeri strain Atlantic rainforest, a hypothesis yet to be confirmed by identification of this agent in human clinical samples. Although this hypothesis has not been confirmed, it is noteworthy that we found the pathogenic strain Atlantic rainforest in SC, where it is potentially transmitted to humans by the ticks $A$. ovale and A. aureolatum; this second species is also an important human-biting tick in Brazil (Guglielmone et al. 2006). Interestingly, another pathogenic strain of $R$. parkeri is transmitted by the tick Amblyomma triste in Uruguay and Argentina (Venzal et al. 2004, Romer et al. 2011); however, this tick species is not known to be present in SC.

Most of the spotted fever cases of SC have been reported in the Vale do Itajaí region, especially in Blumenau (Silva 2009), where we found most of the ticks infected by this agent in the present study. However, we also found this rickettsia in $A$. ovale ticks from two other municipalities (Águas Mornas and Urussanga), where human spotted fever has never been confirmed. Thus, clinicians should be alert to the possible occurrence of human spotted fever in these two areas. 
TABLE

Ticks collected in the state of Santa Catarina, Brazil during 2006-2008 and tested by polymerase chain reaction for rickettsial infection

\begin{tabular}{|c|c|c|c|c|c|c|}
\hline \multirow[b]{2}{*}{ Region } & \multirow[b]{2}{*}{ Municipality } & \multirow[b]{2}{*}{$\begin{array}{l}\text { Geographic } \\
\text { coordinates }\end{array}$} & \multicolumn{4}{|c|}{ Ticks } \\
\hline & & & Species & $\begin{array}{l}\text { Tested } \\
\text { (n) }\end{array}$ & $\begin{array}{c}\text { Infected } \\
\text { n (\%) }\end{array}$ & $\begin{array}{l}\text { Rickettsia } \\
\text { species }\end{array}$ \\
\hline \multirow[t]{5}{*}{ Norte } & Araquari & $-26.37 \mathrm{~S}-48.72 \mathrm{~W}$ & Amblyomma aureolatum & 1 & 0 & - \\
\hline & & & Amblyomma ovale & 1 & 0 & - \\
\hline & & & Dermacentor nitens & 5 & 0 & - \\
\hline & Joinvile & $-26.30 \mathrm{~S}-48.84 \mathrm{~W}$ & A. aureolatum & 3 & 0 & - \\
\hline & & & Amblyomma tigrinum & 1 & 0 & - \\
\hline \multirow[t]{10}{*}{ Região Serrana } & Bom Retiro & $-27.79 \mathrm{~S}-49.48 \mathrm{~W}$ & A. aureolatum & 4 & 0 & - \\
\hline & Capão Alto & $-27.93 \mathrm{~S}-50.51 \mathrm{~W}$ & A. tigrinum & 4 & 0 & - \\
\hline & Coxilha Rica & $-28.12 \mathrm{~S}-52.29 \mathrm{~W}$ & A. tigrinum & 2 & 0 & - \\
\hline & Curitibanos & $-27.28 \mathrm{~S}-50.58 \mathrm{~W}$ & A. aureolatum & 4 & 0 & - \\
\hline & Lages & $-27.81 \mathrm{~S}-50.32 \mathrm{~W}$ & A. aureolatum & 37 & 0 & - \\
\hline & & & A. tigrinum & 3 & 0 & - \\
\hline & Monte Castelo & $-26.46 \mathrm{~S}-50.23 \mathrm{~W}$ & A. aureolatum & 2 & 0 & - \\
\hline & Otacílio Costa & $-27.48 \mathrm{~S}-50.12 \mathrm{~W}$ & A. aureolatum & 3 & 0 & - \\
\hline & Santa Isabel & $-28.10 \mathrm{~S}-49.98 \mathrm{~W}$ & A. aureolatum & 2 & 0 & - \\
\hline & Urubici & $-28.01 \mathrm{~S}-49.59 \mathrm{~W}$ & A. aureolatum & 1 & 0 & - \\
\hline \multirow[t]{14}{*}{ Vale do Itajaí } & Barra Velha & $-26.63 \mathrm{~S}-48.68 \mathrm{~W}$ & Amblyomma cajennense & 1 & 0 & - \\
\hline & & & Rhipicephalus sanguineus & 2 & 0 & - \\
\hline & Blumenau & $-26.91 \mathrm{~S}-49.06 \mathrm{~W}$ & A. aureolatum & 28 & $3(10.7)$ & Rickettsia parkeri \\
\hline & & & A. ovale & 34 & $1(2.9)$ & R. parkeri \\
\hline & & & Amblyomma longirostre & 1 & $1(100)$ & Rickettsia amblyommii \\
\hline & & & R. sanguineus & 25 & $1(4.0)$ & R. parkeri \\
\hline & & & Rhipicephalus microplus & 1 & 0 & - \\
\hline & Itapema & $-27.09 \mathrm{~S}-48.61 \mathrm{~W}$ & A. cajennense & 1 & 0 & - \\
\hline & & & $R$. sanguineus & 1 & 0 & - \\
\hline & Rio do Sul & $-27.21 \mathrm{~S}-49.64 \mathrm{~W}$ & A. aureolatum & 1 & 0 & - \\
\hline & Salete & $-26.98 \mathrm{~S}-50.00 \mathrm{~W}$ & A. aureolatum & 1 & 0 & - \\
\hline & Taió & $-27.11 \mathrm{~S}-49.99 \mathrm{~W}$ & A. aureolatum & 5 & 0 & - \\
\hline & & & A. ovale & 3 & 0 & - \\
\hline & & & Amblyomma dubitatum & 4 & 0 & - \\
\hline \multirow[t]{5}{*}{ Grande Florianópolis } & Águas Mornas & $-27.69 \mathrm{~S}-48.82 \mathrm{~W}$ & A. aureolatum & 12 & 0 & - \\
\hline & & & A. ovale & 5 & $1(20)$ & R. parkeri \\
\hline & Florianópolis & $-27.59 \mathrm{~S}-48.54 \mathrm{~W}$ & $R$. sanguineus & 2 & 0 & - \\
\hline & São João Batista & $-27.27 \mathrm{~S}-48.84 \mathrm{~W}$ & A. aureolatum & 2 & 0 & - \\
\hline & & & A. ovale & 1 & 0 & - \\
\hline \multirow[t]{2}{*}{ Sul } & Urussanga & $-28.51 \mathrm{~S}-49.32 \mathrm{~W}$ & A. aureolatum & 19 & 0 & - \\
\hline & & & A. ovale & 38 & $1(2.6)$ & R. parkeri \\
\hline Total & & & & 260 & $8(3.1)$ & \\
\hline
\end{tabular}

In the study of Sabatini et al. (2010) in an Atlantic rainforest area of SP, the tick $A$. ovale was found to occur only at low-elevation areas $(<100 \mathrm{~m}$ above sea level), whereas the tick $A$. aureolatum tick was found to occur only at higher elevation areas ( $>700 \mathrm{~m})$. Interesting, Sabatini et al. (2010) found no A. aureolatum infected by $R$. parkeri strain Atlantic rainforest, whereas at low elevation, this rickettsia was found in $A$. ovale and in one $R$. sanguineus tick collected from a dog. In the present study, we report for the first time $A$. aureolatum ticks infected with the Atlantic rainforest strain. However, in contrast to the situation reported by Sabatini et al. (2010) in SP, in 
Blumenau (elevation $\approx 150 \mathrm{~m}$ ) both $A$. ovale and A. aureolatum occurred sympatrically, many times infesting the same individual hosts (data not shown). In contrast, many A. aureolatum and no A. ovale were collected from dogs in the municipality of Lages, a high-elevation area $(\approx 900$ m) of SC. Because we found no A. aureolatum infected with the Atlantic rainforest strain in Lages or in other areas of SP where this tick does not occur sympatrically with A. ovale (Pinter \& Labruna 2006, Moraes-Filho et al. 2009), it is possible that the Rickettsia-infected A. aureolatum ticks of the present study acquired the infection through horizontal transmission while feeding on the same dogs as infected $A$. ovale ticks. However, this mechanism must be evaluated in future studies encompassing larger samples of questing and feeding ticks.

A single A. longirostre adult tick, collected on the ground, was shown to be infected by $R$. amblyommii strain AL. This rickettsial strain was recently found in the immature stages (5 larvae and 1 nymph) of $A$. longirostre collected from passerine birds in SP (Ogrzewalska et al. 2008). Although different strains of $R$. amblyommii have been reported to infect different tick species of the New World (Labruna 2009, Castellaw et al. 2010, Ogrzewalska et al. 2010, Bermúdez et al. 2011), the pathogenicity of $R$. amblyommii in humans remains to be demonstrated. Interestingly, there is serological evidence suggesting that it is a human pathogen in the United States (Apperson et al. 2008).

Clinical cases of Brazilian spotted fever have been reported in SC since 2003, but the Rickettsia species involved in these cases has never been identified. We report for the first time the Rickettsia species infecting human-biting ticks in SC. Although it is possible that the $R$. parkeri strain Atlantic rainforest is the causative agent of some of the human spotted fever cases that have been diagnosed by serology in that state, it is possible that other strains of R. parkeri or even other Rickettsia species are also causing spotted fever in SC. Further studies are warranted to better understand the pathogenic rickettsiae in southern Brazil.

Herein, we considered the Atlantic rainforest strain to belong to the species $R$. parkeri based on the gene sequence-based criteria recently proposed for identification of new Rickettsia isolates (Fournier et al. 2003), as discussed by Spolidorio et al. (2010). However, we are aware that the species definition for Rickettsia remains a controversial issue, without a major consensus among rickettsiologists (Walker \& Ismail 2008, Fournier \& Raoult 2009, Goddard 2009).

\section{REFERENCES}

Angerami RN, da Silva AM, Nascimento EM, Colombo S, Wada MY, dos Santos FC, Mancini DM, de Oliveira RC, Katz G, Martins EC, da Silva LJ 2009. Brazilian spotted fever: two faces of a same disease? A comparative study of clinical aspects between an old and a new endemic area in Brazil. Clin Microbiol Infect 2 (Suppl): 207-208.

Angerami RN, Resende MR, Feltrin AF, Katz G, Nascimento EM, Stucchi RS, Silva LJ 2006a. Brazilian spotted fever: a case series from an endemic area in southeastern Brazil: clinical aspects. Ann N Y Acad Sci 1078: 252-254.
Angerami RN, Resende MR, Feltrin AF, Katz G, Nascimento EM, Stucchi RS, Silva LJ 2006b. Brazilian spotted fever: a case series from an endemic area in southeastern Brazil: epidemiological aspects. Ann N Y Acad Sci 1078: 170-172.

Apperson CS, Engber B, Nicholson WL, Mead DG, Engel J, Yabsley MJ, Dail K, Johnson J, Watson DW 2008. Tick-borne diseases in North Carolina: is "Rickettsia amblyommii" a possible cause of rickettsiosis reported as Rocky Mountain spotted fever? Vector Borne Zoonotic Dis 8: 1-10.

Barros-Battesti DM, Arzua M, Bechara GH 2006. Carrapatos de importância médico-veterinária da Região Neotropical: um guia ilustrado para identificação de espécies, Vox/International Consortium on Ticks and Tick-borne Diseases (ICTTD-3)/Butantan, São Paulo, 223 pp.

Bermúdez CS, Zaldívar AY, Spolidorio MG, Moraes-Filho J, Miranda RJ, Caballero CM, Mendoza Y, Labruna MB 2011. Rickettsial infection in domestic mammals and their ectoparasites in El Valle de Antón, Coclé, Panama. Vet Parasitol 177: 134-138.

Castellaw AH, Showers J, Goddard J, Chenney EF, Varela-Stokes AS 2010. Detection of vector-borne agents in lone star ticks, Amblyomma americanum (Acari: Ixodidae), from Mississippi. J Med Entomol 47: 473-476.

Fournier PE, Dumler JS, Greub G, Zhang J, Wu Y, Raoult D 2003. Gene sequence-based criteria for identification of new Rickettsia isolates and description of Rickettsia heilongjiangensis sp. nov. J Clin Microbiol 41: 5456-5465.

Fournier PE, Raoult D 2009. Current knowledge on phylogeny and taxonomy of Rickettsia spp. Ann N Y Acad Sci 1166: 1-11.

Goddard J 2009. Historical and recent evidence for close relationships among Rickettsia parkeri, $R$. conorii, $R$. africae, and $R$. sibirica: implications for rickettsial taxonomy. J Vector Ecology 34: $238-242$.

Guglielmone AA, Beati L, Barros-Battesti DM, Labruna MB, Nava S, Venzal JM, Mangold AJ, Szabo MP, Martins JR, GonzalezAcuna D 2006. Ticks (Ixodidae) on humans in South America. Exp Appl Acarol 40: 83-100.

Labruna MB 2009. Ecology of Rickettsia in South America. Ann N Y Acad Sci 1166: 156-166.

Labruna MB, Whitworth T, Horta MC, Bouyer DH, McBride J, Pinter A, Popov V, Gennari SM, Walker DH 2004. Rickettsia species infecting Amblyomma cooperi ticks from an area in the state of São Paulo, Brazil, where Brazilian spotted fever is endemic. J Clin Microbiol 42: 90-98.

Lamas C, Favacho A, Rozental T, Bóia MN, Kirsten AH, Guterres A, Barreira J, de Lemos ER 2008. Characterization of Rickettsia rickettsii in a case of fatal Brazilian spotted fever in the city of Rio de Janeiro, Brazil. Braz J Infect Dis 12: 149-151.

Lemos ER, Alvarenga FB, Cintra ML, Ramos MC, Paddock CD, Ferebee TL, Zaki SR, Ferreira FC, Ravagnani RC, Machado RD, Guimarães MA, Coura JR 2001. Spotted fever in Brazil: a seroepidemiological study and description of clinical cases in an endemic area in the state of São Paulo. Am J Trop Med Hyg 65: 329-334.

Moraes-Filho J, Pinter A, Pacheco RC, Gutmann TB, Barbosa SO, Gonzáles MA, Muraro MA, Cecílio SR, Labruna MB 2009. New epidemiological data on Brazilian spotted fever in an endemic area of the state of São Paulo, Brazil. Vector Borne Zoonot Dis 9: 73-78.

Nascimento EMM, Colombo S, Nagasse-Sugahara TK, Angerami RN, Resende MR, da Silva LJ, Katz G, dos Santos FC 2009. Evaluation of PCR-based assay in human serum samples for diagnosis of fatal cases of spotted fever group rickettsiosis. Clin Microbiol Infect 2 (Suppl): 232-234. 
Nascimento EMM, Gehrke FS, Maldonado RA, Colombo S, Silva LJ, Schumaker TT 2005. Detection of Brazilian spotted fever infection by polymerase chain reaction in a patient from the state of São Paulo. Mem Inst Oswaldo Cruz 100: 277-279.

Ogrzewalska M, Pacheco RC, Uezu A, Ferreira F, Labruna MB 2008. Ticks (Acari: Ixodidae) infesting wild birds in an Atlantic forest area in the state of São Paulo, Brazil, with isolation of rickettsia from the tick Amblyomma longirostre. J Med Entomol 45: 770-774.

Ogrzewalska M, Pacheco RC, Uezu A, Richtzenhain LJ, Ferreira F, Labruna MB 2009. Rickettsial infection in Amblyomma nodosum ticks (Acari: Ixodidae) from Brazil. Ann Trop Med Parasitol 103: 413-425.

Ogrzewalska M, Uezu A, Labruna MB 2010. Ticks (Acari: Ixodidae) infesting wild birds in the eastern Amazon, northern Brazil, with notes on rickettsial infection in ticks. Parasitol Res 106: 809-816.

Parola P, Davoust B, Raoult D 2005. Tick- and flea-borne rickettsial emerging zoonoses. Vet Res 36: 469-492.

Philip RN, Casper EA, Burgdorfer W, Gerloff RK, Hughes LE, Bell EJ 1978. Serologic typing of rickettsiae of the spotted fever group by microimmunofluorescence. J Immunol 121: 1961-1968.

Pinter A, Labruna MB 2006. Isolation of Rickettsia rickettsii and Rickettsia bellii in cell culture from the tick Amblyomma aureolatum in Brazil. Ann N Y Acad Sci 1078: 523-529.

Regnery RL, Spruill CL, Plikaytis BD 1991. Genotypic identification of rickettsiae and estimation of intraspecies sequence divergence for portions of two rickettsial genes. J Bacteriol 173: 1576-1589.

Romer Y, Seijo AC, Crudo F, Nicholson WL, Varela-Stokes A, Nash RR, Paddock CD 2011. Rickettsia parkeri rickettsiosis, Argentina. Emerg Infect Dis 17: 1169-1173.
Rozental T, Eremeeva ME, Paddock CD, Zaki SR, Dasch GA, Lemos ER 2006. Fatal case of Brazilian spotted fever confirmed by immunohistochemical staining and sequencing methods on fixed tissues. Ann N Y Acad Sci 1078: 257-259.

Sabatini GS, Pinter A, Nieri-Bastos FA, Marcili A, Labruna MB 2010. Survey of ticks (Acari: Ixodidae) and their rickettsia in an Atlantic rain forest reserve in the state of São Paulo, Brazil. J Med Entomol 47: 913-916.

Sangioni LA, Horta MC, Vianna MCB, Gennari SM, Soares RM, Galvão MAM, Schumaker TTS, Ferreira F, Vidotto O, Labruna MB 2005. Rickettsial infection in animals and Brazilian spotted fever endemicity. Emerg Infect Dis 11: 265-270.

Silva AMR 2009. Situação epidemiológica da febre maculosa brasileira no estado de Santa Catarina 2003-2008, Diretoria de Vigilância Epidemiológica/Secretaria de Estado de Saúde, Florianópolis, $6 \mathrm{pp}$.

Silva N, Eremeeva ME, Rozental T, Ribeiro GS, Paddock CD, G Ramos EA, Favacho AR, Reis MG, Dasch GA, de Lemos ER, Ko AI 2011. Eschar-associated spotted fever rickettsiosis, Bahia, Brazil. Emerg Infect Dis 17: 275-278.

Spolidorio MG, Labruna MB, Mantovani E, Brandao PE, Richtzenhain LJ, Yoshinari NH 2010. Novel spotted fever group rickettsiosis, Brazil. Emerg Infect Dis 16: 521-523.

Venzal JM, Portillo A, Estrada-Peña A, Castro O, Cabrera PA, Oteo JA 2004. Rickettsia parkeri in Amblyomma triste from Uruguay. Emerg Infec Dis 10: 1493-1495.

Walker DH, Ismail N 2008. Emerging and re-emerging rickettsioses: endothelial cell infection and early disease events. Nat Rev Microbiol 6: 375-386.

Walker DH, Paddock CD, Dumler JS 2008. Emerging and re-emerging tick-transmitted rickettsial and ehrlichial infections. Med Clin North Am 92: 1345-1361. 